\title{
From field geology to earthquake simulation: a new state-of-the-art tool to investigate rock friction during the seismic cycle (SHIVA)
}

\author{
Giulio Di Toro • André Niemeijer • Antonino Tripoli • Stefan Nielsen • \\ Fabio Di Felice $\cdot$ Piergiorgio Scarlato • Giuseppe Spada • \\ Roberto Alessandroni - Giovanni Romeo • Giuseppe Di Stefano • \\ Steven Smith • Elena Spagnuolo • Sofia Mariano
}

Received: 19 February 2010/Accepted: 14 September 2010/Published online: 1 October 2010

(C) Springer-Verlag 2010

\begin{abstract}
Despite considerable effort over the past several decades, the mechanics of earthquake rupture remains largely unknown. Moderate- to large-magnitude earthquakes nucleate at $7-15 \mathrm{~km}$ depth and most information is retrieved from seismology, but information related to the physico-chemical processes active during rupture propagation is below the resolution of this method. An alternative approach includes the investigation of exhumed faults, such as those described here from the Adamello Massif (Italian Alps), and the use of rock deformation apparatus capable of reproducing earthquake deformation conditions in the laboratory. The analysis of field and microstructural/mineralogical/geochemical data retrieved from the large glacier-polished exposures of the Adamello (Gole Larghe Fault) provides information on earthquake source parameters, including the coseismic slip, the rupture directivity and velocity, the dynamic friction and earthquake energy budgets. Some of this information (e.g., the evolution of the friction coefficient with slip) can be tested in the laboratory with the recently installed Slow to HIgh Velocity Apparatus (SHIVA). SHIVA uses two brushless engines (max power $280 \mathrm{~kW}$ ) and an air actuator in a rotary shear configuration (nominally infinite displacement) to slide solid or hollow rock cylinders $(40 / 50 \mathrm{~mm}$ int/ext diameter) at: (1) slip rates ranging from $10 \mu \mathrm{m} \mathrm{s}^{-1}$ up to $9 \mathrm{~m} \mathrm{~s}^{-1}$; (2) accelerations up to $80 \mathrm{~m} \mathrm{~s}^{-2}$; and (3) normal stresses up to
\end{abstract}

The original version of this paper was presented in Venice (November 5-6, 2009) at the meeting "Nature and geodynamics of the lithosphere in Northern Adriatic" sponsored by the Accademia Nazionale dei Lincei, Accademia Nazionale delle Scienze detta dei XL and Istituto Veneto di Scienze, Lettere ed Arti.

G. Di Toro - A. Niemeijer - S. Nielsen · F. Di Felice - P. Scarlato - G. Romeo · G. Di Stefano *

S. Smith · E. Spagnuolo $\cdot$ S. Mariano

Istituto Nazionale di Geofisica e Vulcanologia, Via di Vigna Murata 605, 00143 Rome, Italy

G. Di Toro $(\bowtie)$

Dipartimento di Geoscienze, Università degli Studi di Padova, Via Giotto 1, 35137 Padua, Italy e-mail: giulio.ditoro@unipd.it

A. Tripoli

Via Carlo Giuseppe Bertero, 31, 00156 Rome, Italy

G. Spada $\cdot$ R. Alessandroni

RMP, Meccanica Progettazione Prototipi, Viale Enrico Ortolani 194, 00125 Rome, Italy 
$50 \mathrm{MPa}$. In comparison to existing high-speed friction machines, this apparatus extends the range of sliding velocities, normal stresses and sample size. In particular, SHIVA has been specifically designed to reproduce slip velocities and accelerations that occur during earthquakes. The characterization of rock frictional behavior under these conditions, plus the comparison with natural fault products, is expected to provide important insights into the mechanics of earthquakes.

Keywords Earthquakes - Faults - Fault rocks - Adamello - Rock friction experiments · SHIVA

\section{Introduction}

Earthquakes are abrupt ground accelerations induced by the passage of seismic waves. Wave radiation results from (1) rupture propagation (at $\mathrm{km} \mathrm{s}^{-1}$ ) along faults and (2) frictional interaction of the wall rocks bordering the fault during slip (at $\mathrm{m} \mathrm{s}^{-1}$ ) (Heaton 1990; Scholz 2002). Destructive earthquakes usually nucleate between 7 and $15 \mathrm{~km}$ depth and propagate for tens or hundreds of kilometers along faults (Scholz 2002). As a consequence, most information on earthquake source physics is retrieved from the inversion of seismic waves, interferometric synthetic aperture radar (inSAR) studies and other indirect geophysical approaches (Lee et al. 2002; Kanamori and Brodsky 2004). Although these indirect approaches are extremely useful to investigate earthquakes, their resolution is too low to yield information on the physical and chemical processes that are active during seismic faulting.

Two complementary approaches are the investigation of ancient seismic faults and natural fault products now exposed at the Earth's surface, and the use of experimental rock deformation apparatus capable of reproducing seismic slip conditions in the laboratory. By combining field and experimental studies, in addition to modeling and theoretical investigations, it may be possible to investigate several earthquake-related processes that are out of the range of the (indirect) geophysical methods (Di Toro et al. 2009).

The use of exhumed faults to retrieve information on earthquakes relies on the recognition of fault rocks produced during seismic slip and the presence of geological constraints that allow the determination of ambient conditions during seismic faulting. Until now, the only fault rock unambiguously recognized as a signature of an ancient earthquake is pseudotachylyte (solidified friction melts produced during seismic slip: Sibson 1975). The production of pseudotachylyte results from the passage of the seismic rupture followed by fault slip (Sibson 1975; Swanson 1992). In Fig. 1a, the seismic rupture propagates a mode II self-healing pulse (Heaton 1990). At the rupture tip (Fig. 1b), the stress perturbation during crack propagation induces fracturing in the wall rock under tension (i.e., the southern block for a rupture propagating towards the east along a dextral strike-slip fault: see Sect. 2.3). Rupture propagation is followed by surface refinement through crushing, grinding and flash heating and melting of the initiation gouge (e.g., Rice 2006). Bulk melting occurs where the gouge is highly comminuted and strain rate is higher, though it mainly involves the minerals with the lowest melting point (Spray 1992). With increasing slip, the opposite surfaces are separated by a thin layer of melt. Melting occurs at the wall rocks for rock-rock interaction and for phase transition at the melt-wall rock and meltsurvivor clast boundaries (Nielsen et al. 2008). The melt produced in the slipping zone (SZ) (i.e., the fault vein) is mostly injected in the wall rocks, along (a) pre-rupture fractures (if the rupture is propagating along a pre-existing fault), and (b) new fractures produced under the dynamic transient stress field at the rupture tip during propagation and due to the 
a

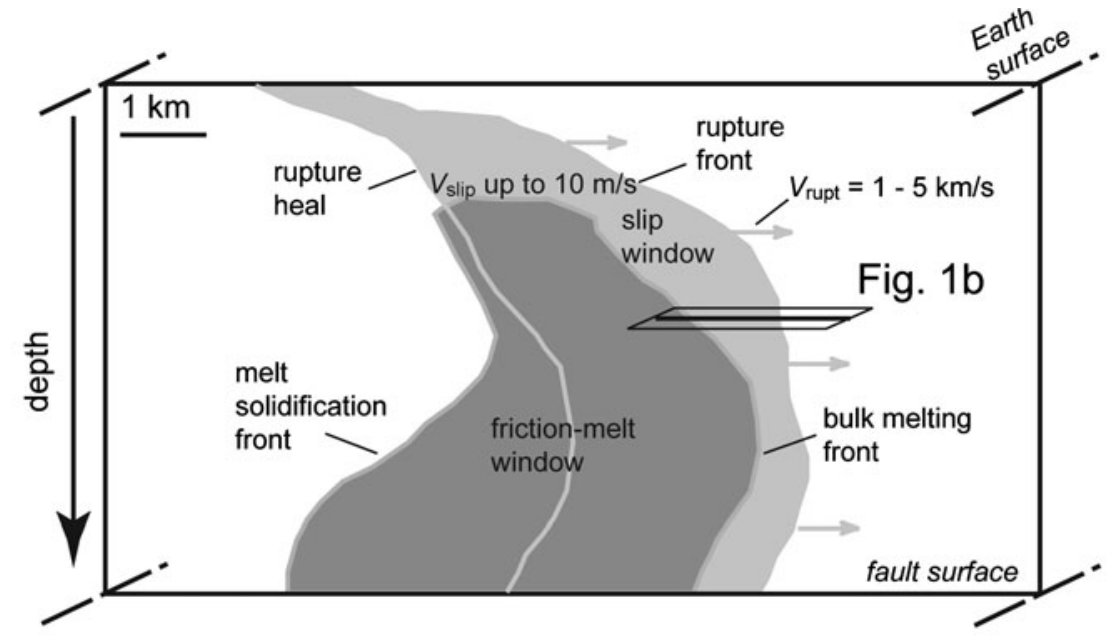

b

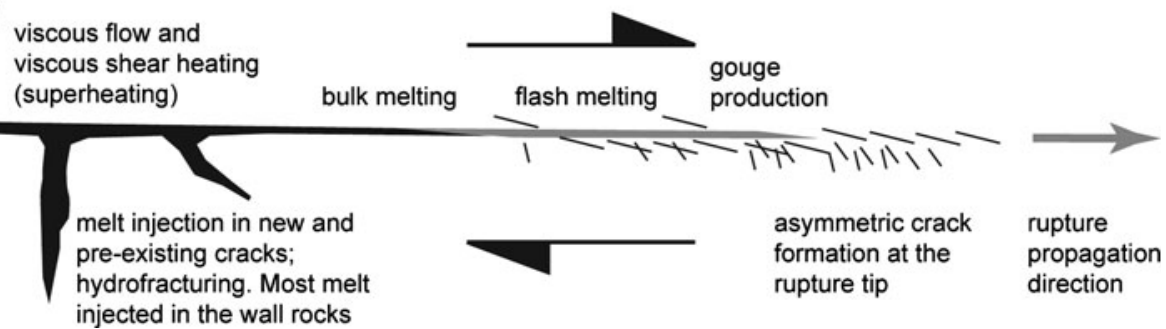

Fig. 1 Model of pseudotachylytes production (modified from Swanson 1992). a Propagation of a seismic self-healing pulse mode II crack. The fracture propagates toward the right side (as indicated by the gray arrows) at a speed $V_{\text {rup }} t$ in the range between 1 and $5 \mathrm{~km} \mathrm{~s}^{-1}$. Behind the rupture front, slip is restricted to a band (light gray area, in large part overlapped by the dark gray area of presence of friction melts). The slipping area is a few $\mathrm{km}$ wide. As the slipping area moves behind the fracture front, friction melt is produced after some refinement along the fault plane and may survive for some time (friction melt window) after the cessation of slip. b Enlargement of the rupture along the fault section shown in a. The rupture propagates to the right and the sense of shear is dextral. The stress perturbation induced by the propagation of the crack produces fractures in the lower block under tensional transient stress (see Sect. 2.3). Gouge production and comminution at the rupture tip are followed by flash melting (i.e., melting at asperity contacts) and bulk melting. Wall rocks interaction and viscous shear heating in the melt layer allow the achievement of extremely high temperatures (superheated frictional melts, Di Toro and Pennacchioni 2004; Nielsen et al. 2008). Most melt is injected in the wall rocks (see Fig. 2c, d)

volume increase related to the melting of the rock. The melt is largely dragged and injected in the wall rocks but a small percentage of melt still remains along the slipping zone. Under these conditions, the fault is lubricated by friction melts (see Sect. 2.1). Once the elastic strain energy stored in the wall rocks that drives the propagation of the rupture is released, the slip rate drops down, and the viscous strength of the melt layer increases instantaneously (mainly because of cooling), leading to the healing of the rupture. The process described above may occur in 1-10 s at most, consistent with rise times typical of earthquakes (Heaton 1990). Instead, the melt injected into the wall rocks or pounding in dilational jogs along the fault vein (i.e., reservoirs) cools slowly, from seconds to minutes, depending on the peak temperature of the melt, the temperature of the host rock and the thickness of the melt layer: melt might be still present after the healing of the rupture 
Fig. 2 The Gole Larghe Fault Zone in the Adamello batholith (Italy). a Tectonic sketch map of the Adamello region showing the location of the Gole Larghe Fault, and of the glaciated outcrops (star) analyzed in detail in this contribution. b Field view of the exposures of the Gole Larghe Fault Zone. The presence of deep creeks allows a three-dimensional view of the fault zone. The fault zone is made of about 200 sub-parallel strike-slip faults (some indicated by arrows). c Photomosaic showing a pseudotachylytebearing fault zone. The excellent exposure allows the detailed mapping of the pseudotachylyte vein network. d Drawing of the pseudotachylytes from the photomosaic of c. The orientation of the fractures filled by pseudotachylyte was used to reconstruct the seismic rupture directivity. e Exceptionally thick pseudotachylyte fault vein, which corresponds to a dilational jog along the fault. The darker rims at the border of the vein are friction melt chilled margins (see Di Toro and Pennacchioni 2004 for details). f Area-weighted rose diagram showing the orientation of the injection veins filled by pseudotachylyte from 29 fault segments of the Gole Larghe Fault Zone. The fractures are measured clockwise from the east side of the fault (see arrow in d). About $70 \%$ of the fractures are toward the south

(friction melt window in Fig. 1a). The solidification of the melt produces the pseudotachylyte.

As a consequence, pseudotachylytes retain a wealth of information about earthquake source mechanics (Di Toro et al. 2009). In this contribution, we will first describe estimates of several earthquake source parameters (Di Toro et al. 2005a, b, 2006, 2009; Pittarello et al. 2008) retrieved from an exceptional field exposure located in the Southern Alps (Italy, Di Toro and Pennacchioni 2004; Pennacchioni et al. 2006). Then, we will introduce a new experimental apparatus designed to investigate seismic slip in the laboratory that has recently been installed in the High-Pressure High-Temperature laboratories of the Istituto Nazionale di Geofisica e Vulcanologia (INGV).

\section{Field geology and earthquake mechanics}

The earthquake source parameters described here were retrieved from the Gole Larghe Fault Zone, a 30 Ma old, pseudotachylyte-bearing, dextral strike-slip fault exhumed from about $10 \mathrm{~km}$ depth (Di Toro and Pennacchioni 2004; Pennacchioni et al. 2006). The Gole Larghe Fault Zone crosscuts the Adamello tonalitic batholith (Italian Alps, Venturelli et al. 1984) and it is a southern branch of the Tonale line, a segment of the Periadriatic Lineament (i.e., the major fault system of the Alps, Schmid et al. 1989; Fig. 2a). The fault zone is exposed in glacially polished, un-weathered outcrops that allow a three-dimensional view of the fault zone structure. The fault zone consists of an array of around 200 main east-west striking sub-parallel cataclastic horizons (Di Toro and Pennacchioni 2005; Fig. 2b-d). Offset markers such as dykes and xenoliths allow an estimate of the displacement accommodated by the individual faults. Importantly, some of the fault segments host a continuous layer of pseudotachylyte (Fig. 2e), indicating the passage of earthquake ruptures. Some of the pseudotachylytes preserve microstructural and field evidence suggesting that they record only one seismic rupture. Pseudotachylyte also fills fractures (i.e., injection veins) departing from the main fault (Fig. 2d, f). The analysis of the pseudotachylyte and of the fault and fracture networks allows us to estimate (1) the dynamic friction during seismic slip, (2) the energy budget of the ancient earthquakes and (3) the direction of propagation of the ancient earthquakes; (1) and (2) are difficult to retrieve through seismological methods (e.g., Guatteri and Spudich 1998, 2000; Scholz 2002).

\subsection{Dynamic friction during seismic slip}

Interpretation of geophysical and seismological data suggests a variety of coseismic processes that can be explained by a low friction coefficient $\mu\left(=\tau / \sigma_{\mathrm{n}}\right.$, where $\tau$ is the shear 

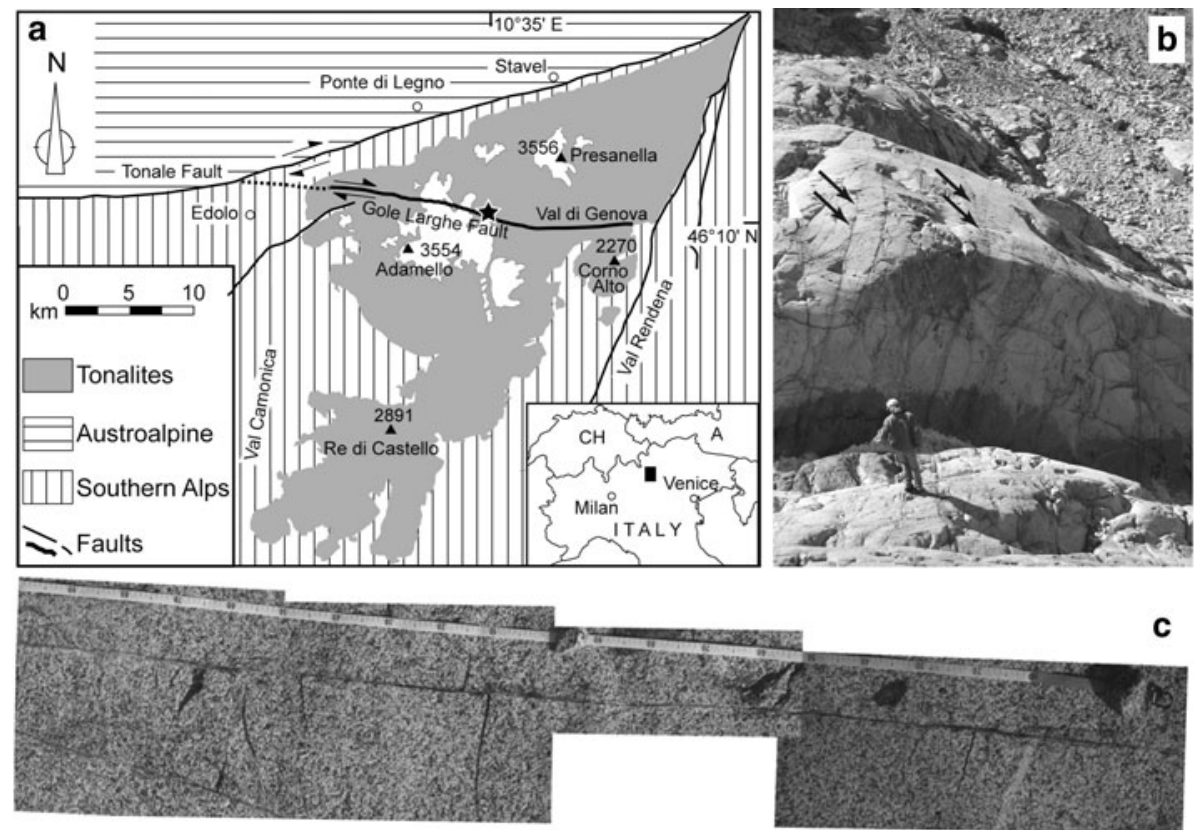

d
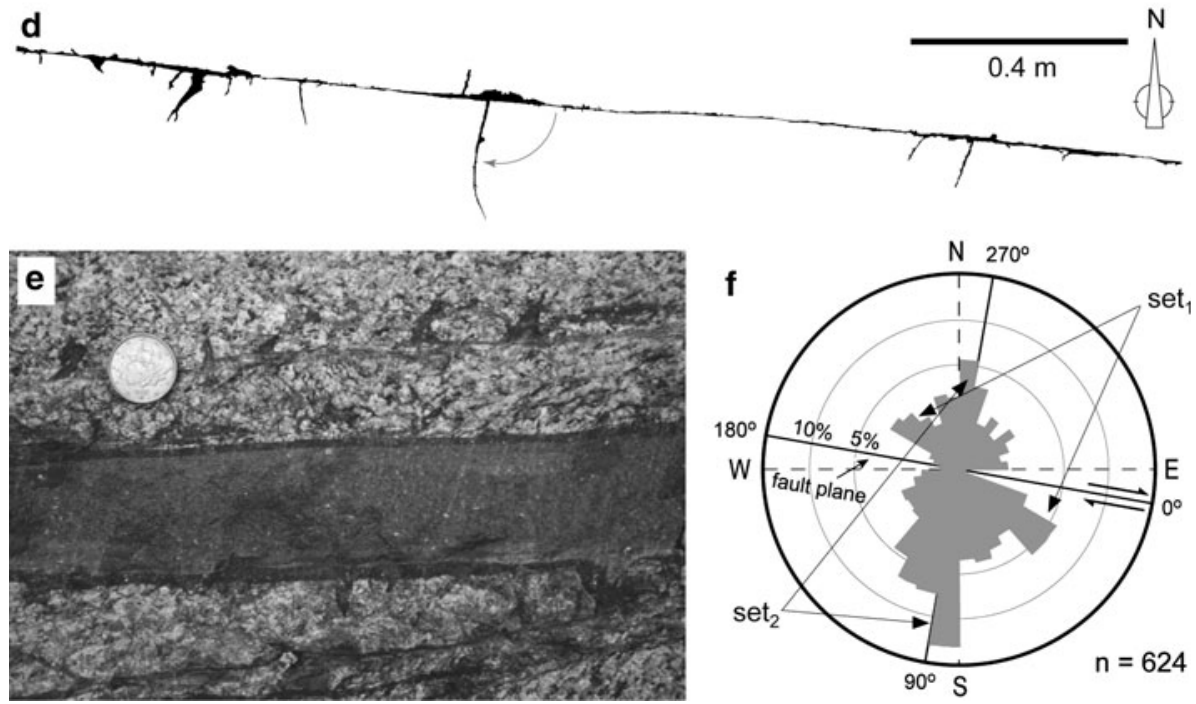

stress and $\sigma_{\mathrm{n}}$ is the stress normal to the fault): for instance, the heat flow paradox (Lachenbruch 1980), the type of rupture propagation (Beeler and Tullis 1996; Zheng and Rice 1998) or the increase of radiated energy with earthquake size (Mayeda and Walter 1996). Several fault dynamic weakening mechanisms have been proposed to explain this (Tullis 2008; Wibberley et al. 2008), although the dynamic friction coefficient cannot easily be retrieved from seismic inversion data (Scholz 2002). One of the proposed weakening mechanisms is melt lubrication (McKenzie and Brune 1972), based on the observation that solidified friction melts (pseudotachylytes) decorate some exhumed faults 
(Sibson 1975). Assuming that most frictional work during faulting is converted into heat (i.e., the energy associated with the creation of new surfaces is negligible, see Sect. 2.2), it is possible to determine the average shear stress during seismic slip $\tau_{\mathrm{f}}$ from natural pseudotachylytes (Sibson 1975) if the average thickness $w_{\mathrm{av}}$ of the pseudotachylyte vein and the displacement $d$ accommodated by the fault to produce that melt layer are known (Di Toro et al. 2005a, 2006):

$$
\tau_{\mathrm{f}}=\rho\left[(1-\phi) H+c_{p}\left(T_{\mathrm{i}}-T_{\mathrm{hr}}\right)\right] w_{\mathrm{av}} / d \quad(\mathrm{~Pa}) .
$$

In Eq. $1, \rho=2,350 \mathrm{~kg} \mathrm{~m}^{-3}$ is the melt density, $\phi=0.2$ is the volume ratio of lithic clasts (clasts that survived from melting) within the pseudotachylyte, $H=3.28 \times 10^{5} \mathrm{~J} \mathrm{~kg}^{-1}$ is the latent heat of fusion, $c_{p}=1,180 \mathrm{~J} \mathrm{~kg}^{-1} \mathrm{~K}^{-1}$ is the specific heat at constant pressure at $1,300 \mathrm{~K}$ and $\left(T_{\mathrm{i}}-T_{\mathrm{hr}}\right)=1,200 \mathrm{~K}$ is the difference between initial melt temperature and host rock temperature (these values were determined for the Gole Larghe Fault pseudotachylytes and can be found in Di Toro et al. 2004). A reliable estimate of $\tau_{\mathrm{f}}$ can only be performed on exceptional fault exposures, because coseismic fault slip and pseudotachylyte volume must be well constrained. Based on Eq. 1, exhumed pseudotachylyte-bearing faults from the Adamello Massif indicate a $\tau_{\mathrm{f}}$ ranging from 12.9 to $41.8 \mathrm{MPa}$ at $10 \mathrm{~km}$ in depth (Di Toro et al. 2006). Since the normal stress to the fault at the time of seismic faulting is estimated to range between 110 and $200 \mathrm{MPa}$ (Di Toro et al. 2005a, b), this results in an average friction coefficient of $<0.25$. Such low dynamic friction during seismic slip in the presence of melts has been confirmed by theoretical and experimental analyses (Nielsen et al. 2008; Di Toro et al. 2009). It follows that at intermediate crustal depths, low fault strength and melt lubrication can occur during seismic faulting.

\subsection{Earthquake energy budgets}

Energy partitioning is one of the main parameters controlling earthquake physics. Theoretical work suggests that during an earthquake, the mechanical work per unit fault surface is partitioned into heat $Q$ and surface energy $U_{\mathrm{s}}$ (energy required to create new surfaces in the slipping zone and wall rock) (e.g., Kostrov and Das 1988; Cocco et al. 2006):

$$
W_{\mathrm{f}}=Q+U_{\mathrm{s}} \quad\left(\mathrm{J} \mathrm{m}^{-2}\right) .
$$

The mechanical work partitioning defined in Eq. (2) cannot be estimated by seismological analyses, because it is impossible to evaluate the surface energy and heat created during dynamic sliding from seismic waves. In pseudotachylyte-bearing faults from the Gole Larghe Fault Zone, it is possible to estimate $Q$ and $U_{\mathrm{s}}$ from field and microstructural analyses of a fault segment. Frictional heat $Q$ is estimated from the thickness of pseudotachylyte (Di Toro et al. 2005a, b; Pittarello et al. 2008):

$$
Q=\left[H(1-\phi)+c_{p}\left(T_{\mathrm{m}}-T_{\mathrm{hr}}\right)\right] \rho w_{\mathrm{av}} \quad\left(\mathrm{J} \mathrm{m}^{-2}\right) .
$$

In the case of the selected pseudotachylyte fault segment, $w_{\mathrm{av}}$ was $5.9 \mathrm{~mm}$, which yielded $Q \sim 27 \mathrm{MJ} \mathrm{m}^{-2}$. The surface energy produced during rupture propagation is (Chester et al. 2005):

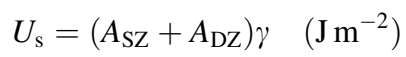

where $A_{\mathrm{SZ}}$ and $A_{\mathrm{DZ}}$ are the new surface per unit fault area ( $A_{\mathrm{SZ}}$ and $A_{\mathrm{DZ}}$ are dimensionless) produced in the slipping zone (Fig. 3) and in the damage zone (DZ, i.e., wall rocks), respectively, and $\gamma$ is the specific surface energy $\left(1-10 \mathrm{~J} \mathrm{~m}^{-2}\right.$ in silica-bearing minerals). 

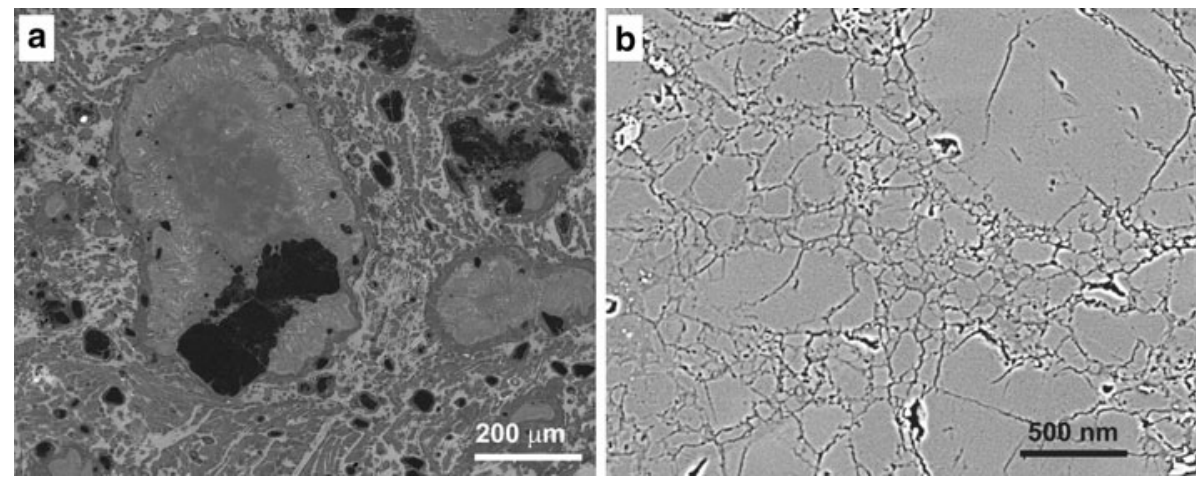

Fig. 3 Microstructures in pseudotachylyte (Field Emission Back Scattered Electron Images). a Survivor polymineralic clasts of plagioclase and quartz are suspended in the pseudotachylyte matrix (e.g., Shand 1916). Clasts are rimmed by elongated plagioclase microlites resulting from crystallization of the friction melt. Flow structures wrap the clasts. b Core of plagioclase survivor clasts. The clast is internally fragmented. Such dense fragmentations is absent in the wall rocks, suggesting that it is the result of seismic slip. The determination of the fragment size distribution allowed to estimate the surface energy produced during seismic slip (for details on the method, see Pittarello et al. 2008)

In the case of the selected pseudotachylyte fault segment, surface energy estimated from Eq. 4 is less than $0.4 \mathrm{MJ} \mathrm{m}^{-2}$ (Pittarello et al. 2008). It follows that in the case of a fault segment exhumed from $10 \mathrm{~km}$ depth, frictional heat is by far the largest energy component dissipated during an earthquake: at such depths, earthquakes are mainly a thermal process.

\subsection{Rupture directivity}

Seismic inversion can constrain rupture directivity (or the direction of propagation of the seismic rupture) and rupture velocity. But given the long recurrence time ( $>100$ years), the instrumented seismological record of repeated large earthquakes along a given fault is rather small and there are no clear indications of repeated earthquake directivity. Field work might yield some information on this issue. For instance, the asymmetry in the distribution and the orientation of pseudotachylyte-bearing secondary fractures around exhumed faults can be used to reconstruct rupture directivity, rupture velocity and fracture energy (the latter is defined as G, or the energy expended to allow crack propagation, Rice 2006; Di Toro et al. 2005b).

In the Gole Larghe Fault Zone, faults and secondary fractures have peculiar features in their shape, attitude and branching patterns. Most of the branching of secondary fractures consists either of tension cracks, up to several $\mathrm{cm}$ thick, lying perpendicular to the main fault line, or thin fractures, lying roughly at $30^{\circ}$ to the fault (consistently with the inferred orientation of the principal horizontal stress) (Fig. 2f). Most interestingly, secondary fractures are asymmetrically distributed on one side of the fault, i.e., into the southern block. Theoretical studies investigated the possible patterns of fault branching that seismic rupture may leave in its trail (Poliakov et al. 2002; Kame et al. 2003; Andrews 2005). In particular, the damage and fractures associated to an earthquake are expected to be asymmetrically distributed on either side of the fault, and to depend on the direction in which the rupture is propagating. In a specific dynamic rupture model reproducing the local stress and rock properties, we predict the asymmetrical creation of secondary fractures and 
tension cracks, based on the near-field, dynamic stress radiation (Di Toro et al. 2005b). The statistically significant asymmetric distribution (624 fractures over 29 different fault segments) of pseudotachylyte-bearing fractures shown in Fig. $2 \mathrm{f}$ is compatible with a dominant propagation direction during repeated seismic ruptures, subsonic fracture propagation velocities (close to Rayleigh wave velocity) and $G$ values ranging from 8 to $67 \mathrm{MJ} \mathrm{m} \mathrm{m}^{-2}$ (Di Toro et al. 2005b). The calculated values for the fracture energy are in the range of the heat estimated for some of these fault segments $\left(27 \mathrm{MJ} \mathrm{m}^{-2}\right.$, see Sect. 2.2) and suggest that, when compared with the estimated surface energy (0.4 $\mathrm{MJ} \mathrm{m}^{-2}$, see Sect. 2.2), most of the so-called seismological fracture energy is in the form of heat.

\section{Friction experiments and earthquake mechanics}

Earthquake sources mostly originate on pre-existing faults and, as a consequence, the frictional behavior of faults is of paramount importance in controlling seismic rupture and slippage (Marone 1998; Scholz 1998). In the last 45 years, experimental studies of friction instabilities on pre-existing surfaces (e.g., Brace and Byerlee 1966; Dieterich 1978) have made valuable contributions to our understanding of the mechanics of seismic faulting which resulted in the definition of a constitutive equation for the friction coefficient (Dieterich 1979; Ruina 1983; Tullis 1988). These “conventional rock friction" experiments (Lockner and Beeler 2002) have generally been conducted in biaxial and triaxial apparatus at low slip rates $\left(<10 \mu \mathrm{m} \mathrm{s}^{-1}\right)$ and limited displacements $(<10 \mathrm{~mm})$ (Byerlee 1978). The well-established empirical results from conventional rock friction experiments have found broad application in earthquake modeling (Scholz 1998), even though seismic slip rates $\left(1-10 \mathrm{~m} \mathrm{~s}^{-1}\right)$ and displacements $(0-20 \mathrm{~m})$ are up to five or six orders of magnitude larger. Although several seismological observations are consistent with the results of these conventional rock friction experiments, other recent field observations suggest a significant decrease in dynamic fault strength with slip (slip weakening) and slip rate (velocity weakening) during earthquakes (Tullis 2008). To explain these field observations, different coseismic fault weakening mechanisms have been proposed from a theoretical point of view, including thermal pressurization (Sibson 1973; Bizzarri and Cocco 2006), melt lubrication (Jeffreys 1942; Sibson 1975), acoustic fluidization (Melosh 1996), flash heating and weakening (Rice 2006; Beeler et al. 2008) and elastohydrodynamic lubrication (Brodsky and Kanamori 2001).

Despite the great need for experimental data on fault friction at seismic slip rates (Beeler 2006), the application of normal stresses comparable with those at seismogenic depths $(>100 \mathrm{MPa})$, together with slip rates and displacements (and accelerations) typical of earthquakes, remains a major technical challenge. A first attempt to approach the extreme deformation conditions typical of earthquakes was the installation in the late 1980s of the high-pressure rotary shear apparatus designed by Prof. Terry Tullis (Brown University). This apparatus used a gas medium to confine samples up to $500 \mathrm{MPa}$ and allowed samples to be slid to nominally infinite displacements, although slip rate was limited to a few $\mathrm{mm} \mathrm{s}^{-1}$. A second rotary shear apparatus specifically designed to reproduce seismic slip rates was designed by Prof. Toshihiko Shimamoto (Shimamoto and Tsutsumi 1994) in the late 1980s (HV-1, University of Kyoto, now at Jamstec in Kochi, Japan). The HV-1 has been heavily used and has produced about $90 \%$ of the published high-velocity friction data to the present day. Other experiments approaching and reproducing seismic slip rates have been performed in non-conventional apparatus including industrial frictional welding machines (Spray 1987, 1995), industrial testing machines such 
as the Instron 8500 (Brown University, Di Toro et al. 2004) and the MTS 809 (Padua University, Tisato et al. 2009), the modified torsion Kolsky bar (Yuan and Prakash 2008a), and the plate impact pressure shear friction apparatus (Yuan and Prakash 2008b). This experimental work resulted in the identification of several potential dynamic weakening mechanisms, such as melt lubrication (Hirose and Shimamoto 2005; Spray 2005; Di Toro et al. 2006), thermal decomposition (Han et al. 2007; Brantut et al. 2008), nanoparticle lubrication (Han et al. 2010), and silica gel lubrication (Goldsby and Tullis 2002; Di Toro et al. 2004). However, our understanding of these dynamic weakening processes, and their dependence on normal stress (note that experiments were performed at $<1 \mathrm{MPa}$ in the case of gouges and $<20 \mathrm{MPa}$ in the case of cohesive rocks) and slip rate $\left(<2 \mathrm{~m} \mathrm{~s}^{-1}\right.$ and at constant slip rate conditions with the exception of Sone and Shimamoto 2009), is so limited that they have not yet been explicitly introduced into any earthquake rupture model. Moreover, the samples used in most of these experiments are $<25 \mathrm{~mm}$ in diameter and are often solid cylinders: the combination of these two characteristics yields rather imprecise experimental data. For instance, for a given angular speed, the slip rate increases from the center (where it is virtually zero) to the outer edge of the sample. As a consequence, the so-called "equivalent slip rate", which also constrains the total slip of the sample, is better constrained using larger rings with a small difference between the external and the internal radius (see Eq. 8 for details). Moreover, the differential speed across the sample affects the thermal evolution of the slipping zone: at the sample edge, where the slip rate is higher, the temperature increases faster than at the sample center. This results in uneven thermal dilatancy and normal stress distribution of the specimens, which affects the measured friction (e.g., Kitajima et al. 2010). It follows that the utilization of larger in size and ring-shaped samples will yield more accurate experimental data. Clearly, there is the need for further research, together with the introduction of new experimental and analytical techniques tailored to the investigation of these experimental (and natural) fault products.

To address these problems, several new generation experimental apparatus have been built and installed in the last few years. Most of these apparatus were designed by Prof. Toshihiko Shimamoto and his students and have been installed in Japan: the HV-2 installed at Hiroshima University (designed by Prof. Shimamoto); the rotary shear installed at Kyoto University (designed by Prof. Akito Tsutsumi: Hayashi and Tsutsumi 2010); the rotary shear installed at JAMSTEC Kochi (designed by Dr. Takehiro Hirose and Dr. Wataru Tanikawa); the rotary shear installed at NIED Tsukuba (designed by Prof. Shimamoto and Dr. Kazuo Mizoguchi, Fukuyama and Mizoguchi 2010); the rotary shear at Shizuoka Univ. (designed by Prof. Shimamoto); and the rotary shear at Oklahoma University (USA, designed by Prof. Ze'ev Reches and Dr. David Lockner: Reches et al. 2009). Other rotary shears (HV-3 generation) designed by Prof. Shimamoto will be installed during 2010 in Italy (Padua University), in the United Kingdom (Durham University) and in China (University of Beijing). All the apparatus described above have electric engines with power $<30 \mathrm{~kW}$ and can apply maximum torques of $<440 \mathrm{~N} \mathrm{~m}$ (but at subseismic slip rates) and axial loads $<10$ tons. The new apparatus recently installed at INGV in Rome (SHIVA) is one order of magnitude more powerful $(280 \mathrm{~kW})$, and is capable of deforming samples at slip rates up to $9 \mathrm{~m} \mathrm{~s}^{-1}$, torques of $900 \mathrm{~N} \mathrm{~m}$ at seismic slip rates, and axial loads of 5 tons.

Together with the collection of mechanical data, a major advantage of performing highvelocity rock friction experiments is the production of artificial seismic fault rocks that can be directly compared to natural examples. Currently, pseudotachylytes (solidified melts produced during seismic slip) are the only fault rocks unambiguously recognized as the signature of ancient earthquakes in exhumed faults (Cowan 1999). However, 
pseudotachylyte occurrences are much less widespread than seismic activity in the Earth crust (Sibson and Toy 2006), suggesting that they may not always be produced during earthquakes. It follows that the interpretation of most fault rock assemblages (cataclasites, fault gouges, etc.) in terms of their mechanical behavior and seismic implications remains enigmatic. Production of seismic fault rocks in the laboratory under controlled conditions will allow a comprehensive characterization of the microstructural features produced at seismic slip rates. This promises the opportunity to reveal ancient seismicity of exhumed fault zones and will yield a wealth of information (see Sect. 2) on earthquake mechanics at a fraction of the cost of, for instance, deep fault drilling.

\section{SHIVA: a new high-velocity apparatus}

The design of SHIVA was completed by Eng. Antonino Tripoli (Tripoli 2008) in collaboration with Giulio Di Toro, Stefan Nielsen, Piergiorgio Scarlato and Giovanni Romeo. SHIVA was built under the guidance of Eng. Giuseppe Spada and Roberto Alessandroni at the RMP machine shop during 2009 and installed at INGV on November 20, 2009. The control, acquisition and data elaboration system of SHIVA were developed by Fabio Di Felice, André Niemeijer, Giuseppe Di Stefano and Elena Spagnuolo. The first tests performed on steel and gabbro have shown that SHIVA can impose a wide range of slip velocities $\left(10 \mu \mathrm{m} \mathrm{s}^{-1}\right.$ to $6.5 \mathrm{~m} \mathrm{~s}^{-1}$ for standard hollow-shaped samples with external diameter of $50 \mathrm{~mm}$ and internal diameter of $30 \mathrm{~mm}$ ) and extraordinarily large accelerations (from 0 to $6.5 \mathrm{~m} \mathrm{~s}^{-2}$ in $0.1 \mathrm{~s}$ or $65 \mathrm{~m} \mathrm{~s}^{-2}$ under a normal load of $50 \mathrm{kN}$ ), comparable to those expected for real earthquakes. This performance will, therefore, allow investigation of the entire earthquake cycle: nucleation, seismic slip and post-seismic deformation.

\subsection{Design and performance of the apparatus}

SHIVA is about $4 \mathrm{~m}$ long, $0.9 \mathrm{~m}$ wide and $1.7 \mathrm{~m}$ high and weighs $4,000 \mathrm{~kg}$. The apparatus has a horizontal setup, with the rotary column on one end, the sample chamber in the middle and the stationary loading system side at the other end (Figs. 4, 5). The apparatus is fixed to a reinforced concrete base to reduce vibration and to improve the quality of the measured shear and normal stresses. In the following text, we describe the individual parts of the apparatus (Table 1).

\subsubsection{Rotary motion}

Rotary motion is supplied to the sample pair by two brushless engines (phase motion control): one small engine (Ultract III-U31320C.30.3MYZ000, A in Fig. 4) and one large engine (Ultract III-U720.30.3M00000, B in Fig. 4). The small engine has an operating velocity range of $1-4,000$ RPM (rounds per minute) and a nominal power output of $5.15 \mathrm{~kW}$. The maximum torque ( $T_{\text {eng }}=k_{\mathrm{t}} I$ with $k_{\mathrm{t}}=1.5$ the torque constant and $I=14.4$ A the nominal current for the small engine) produced by the engine is $20 \mathrm{~N} \mathrm{~m}$. The presence of a gearbox (1:225) increases the maximum torque to $4,500 \mathrm{~N} \mathrm{~m}$ $\left(=225 T_{\text {eng }}\right)$. The large engine operates in a velocity range of 1-3,000 RPM and has $k_{\mathrm{t}}=1.65$ and $I=565 \mathrm{~A}$, which results in a peak torque of $932 \mathrm{~N} \mathrm{~m}$ (at 1,800 RPM; $437 \mathrm{~N} \mathrm{~m}$ at 3,000 RPM) and a nominal maximum power output of $280 \mathrm{~kW}$. The power supply to both engines is controlled by an inverter/controller (made by Gefran) which is 


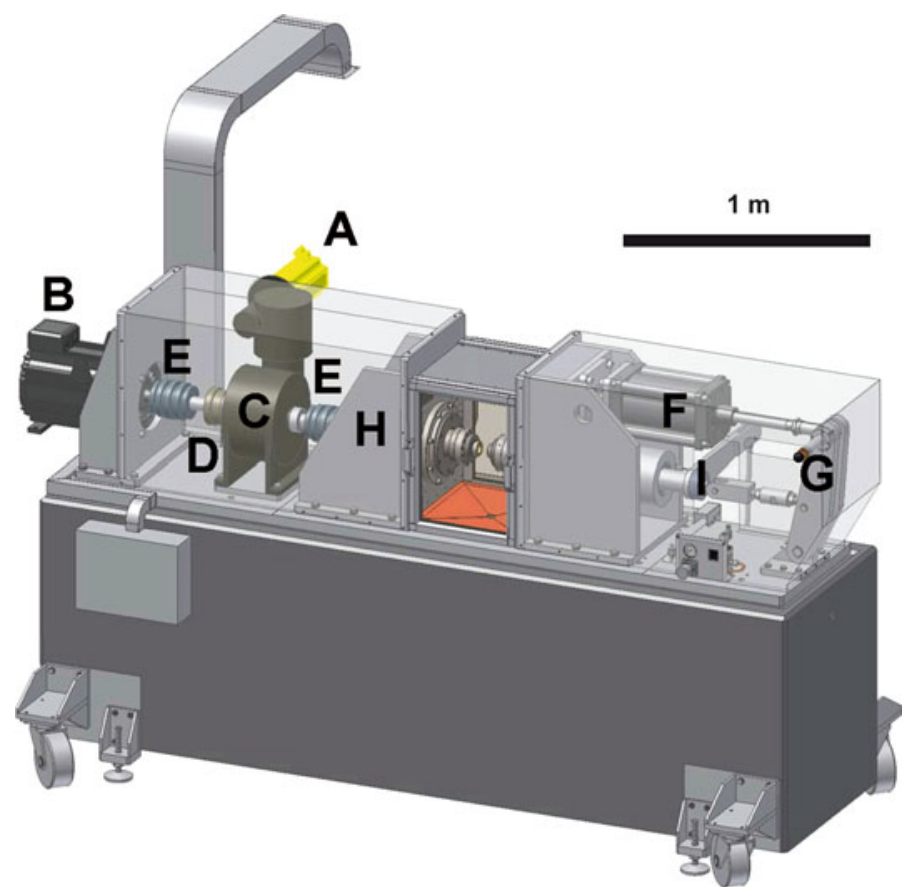

Fig. 4 Sketch of SHIVA. See text for description

supplied with $380 \mathrm{~V}$ (small engine) and $480 \mathrm{~V}$ (large engine). The inverter/controller regulates the supplied current to the engines to reach a rotation velocity which is measured by digital encoders located inside the engines. The small engine is attached to the main rotary shaft via a gearbox (C in Fig. 4), which reduces the maximum speed of the rotary shaft to 17.7 RPM (1:225). The large engine is attached to the rotary shaft via a sprag clutch (made by Reynolds, D in Fig. 4), which allows a transition between the two engines without the loss of motion and torque, so that the rotation is controlled by the engine that moves faster. We consider the addition of the sprag clutch a relevant improvement with respect to previous high-velocity designs. The sprag clutch allows velocity to be stepped up by swapping between the two brushless engines without any reduction in normal stress and torque; this is a real problem with existing high-velocity machines which use electromagnetic clutches to switch between drive shafts. In fact, during the switch, there is a small reduction in normal stress and a large reduction in torque which might harm the quality of the experimental data for the determination of constitutive friction laws. Out-of-plane (rotational) movement and vibrations of the rotary column are dampened by the use of two 1,500 N m BC3 Bellow couplings (E in Fig. 4) and ball-bearing housings.

\subsubsection{Loading system}

Normal load is applied to the sample via an air-actuated pneumatic piston cylinder (built by Camozzi, F in Fig. 4) rated to 10 bar (but it is only used up to 6 bar). Given the internal area of the piston of $314 \mathrm{~cm}^{2}$, the pressure of 6 bar results in a thrust of $18.4 \mathrm{kN}$. A mechanical arm ( $\mathrm{G}$ in Fig. 4) increases the thrust of the piston by a factor of 2.7, so that the 

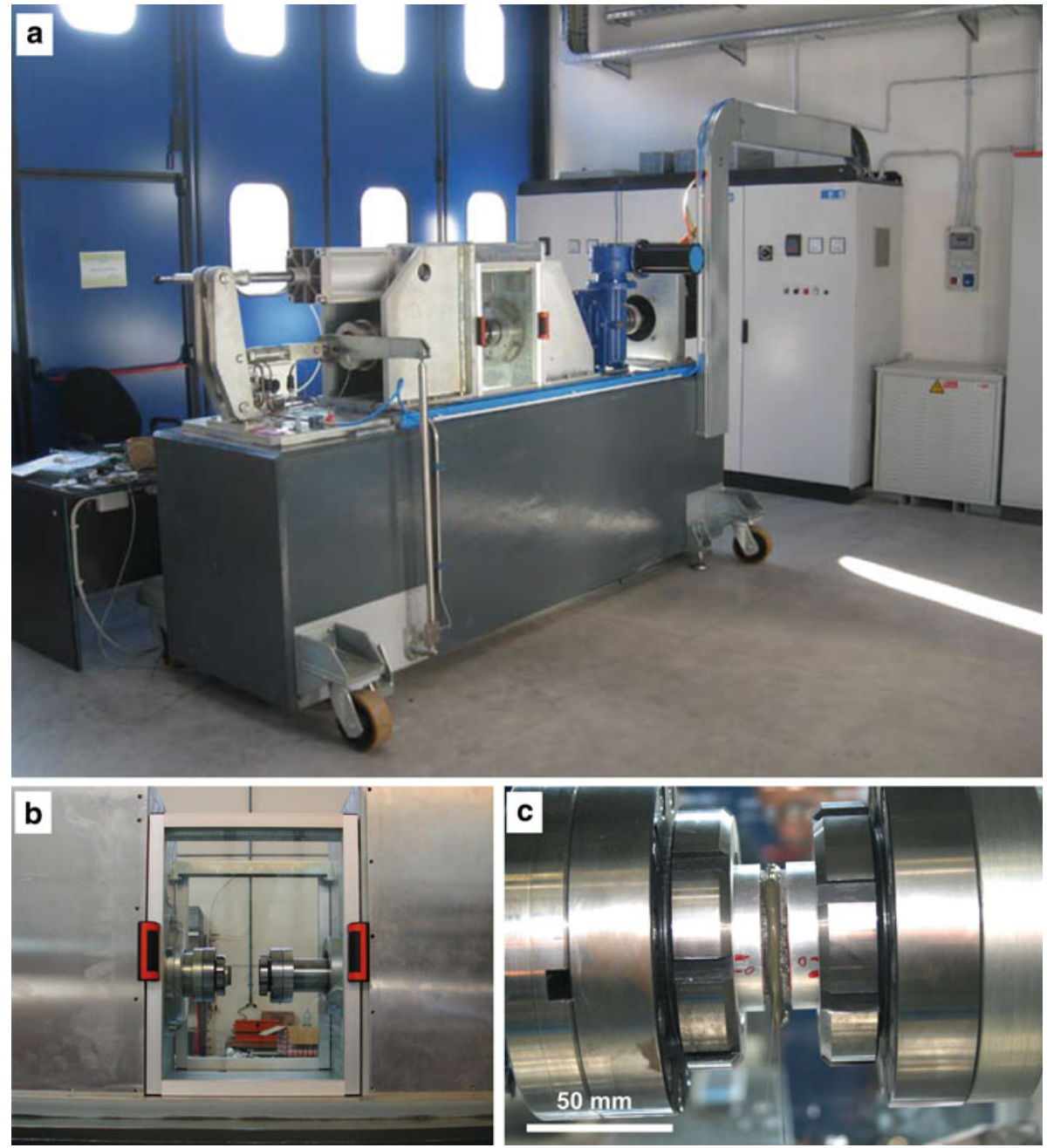

Fig. 5 SHIVA. a The apparatus installed at the HP-HT laboratory in Rome. In the background, the Gefran inverter/controller. b Sample chamber. c Two gabbro samples after the high-velocity friction experiment s007: the artificial pseudotachylyte welds the rocks

maximum load that can be applied is $50 \mathrm{kN}$ (about 5 tons). Pressure is controlled via an electro-valve in parallel with a digital pneumatic regulator. The pneumatic regulator has as an operating range of $0-9$ bar, a resolution of 0.02 bar and a response time of $0.2 \mathrm{~s}$ for a step of $50 \%$ of full scale.

\subsubsection{Measuring system}

Rotational motion of the stationary shaft is impeded by a rigid arm which is attached to a sealed S-beam-type load cell that measures the torque (Applied Measurements Limited). The load cell itself is attached to the bottom of the concrete base. The S-beam load cell has a measuring range of $0-3 \mathrm{kN}$ and a resolution of $0.9 \mathrm{~N}$, which translates to a moment of 
Table 1 Specifications and performances of SHIVA

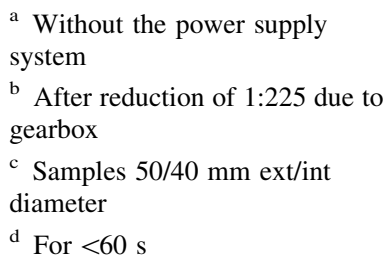

\begin{tabular}{|c|c|}
\hline \multicolumn{2}{|l|}{ SHIVA } \\
\hline Weight $^{\mathrm{a}}(\mathrm{kg})$ & 4,000 \\
\hline Length $^{\mathrm{a}}(\mathrm{mm})$ & 3,500 \\
\hline Height $^{\mathrm{a}}(\mathrm{mm})$ & 1,700 \\
\hline Width $^{\mathrm{a}}(\mathrm{mm})$ & 900 \\
\hline $\operatorname{Max}_{\operatorname{load}^{\mathrm{a}}(\mathrm{kN})}$ & 50 \\
\hline \multicolumn{2}{|l|}{ Small engine } \\
\hline Power supply (V) & 380 \\
\hline Peak power $(\mathrm{kW})$ & 5.15 \\
\hline $\operatorname{Max}_{\operatorname{torque}^{\mathrm{b}}}(\mathrm{N} \mathrm{m})$ & 4,500 \\
\hline Slip rate range ${ }^{c}\left(\mathrm{~mm} \mathrm{~s}^{-1}\right)$ & $0.01-3$ \\
\hline \multicolumn{2}{|l|}{ Large engine } \\
\hline Power supply (V) & 480 \\
\hline Max continuos power $(\mathrm{kW})$ & 40 \\
\hline Peak power $^{\mathrm{d}}(\mathrm{kW})$ & 280 \\
\hline Max torque at $1,800 \mathrm{RPM}(\mathrm{N} \mathrm{m})$ & 932 \\
\hline Max torque at 3,000 RPM $(\mathrm{N} \mathrm{m})$ & 437 \\
\hline Slip rate range ${ }^{\mathrm{c}}\left(\mathrm{m} \mathrm{s}^{-1}\right)$ & $0.001-9$ \\
\hline Max acceleration $^{\mathrm{c}}\left(\mathrm{m} \mathrm{s}^{-2}\right)$ & 80 \\
\hline
\end{tabular}

1,500 and $0.45 \mathrm{~N} \mathrm{~m}$, respectively. Normal load is measured outside the sample chamber, directly behind the mechanical arm (I in Fig. 4), using a $50 \mathrm{kN}$ load cell (Applied Measurements Limited) and a resolution of $2.5 \mathrm{~N}$. We calibrated the S-type load cell by applying a known moment to the sample holder, and the normal load cell by deforming a dynamometer in the sample chamber, thus automatically correcting for any load supported by the ball-bearing housing. Rotational displacement is measured by a digital encoder (Renishaw) with marks every $20 \mu \mathrm{m}$, which is located directly behind the ball-bearing housing of the rotational side ( $\mathrm{H}$ in Fig. 4). The resolution of the reader head (Signum) with this encoder is $0.2 \mu \mathrm{m}$. Shortening of the sample is measured via a spring-loaded DVDT position sensor located behind the rigid arm that halts rotational motion and by a LVDT located in the sample chamber close to the sample. The DVDT has a full scale range of $0-50 \mathrm{~mm}$ and a resolution of $50 \mu \mathrm{m}$. The LVDT has a full range of $0-3 \mathrm{~mm}$ and a resolution of $30 \mathrm{~nm}$.

\subsubsection{Sample holders}

The apparatus was designed for cylinders with an outside diameter of $50 \mathrm{~mm}$ and an inside diameter ranging from 0 (solid cylinders) to $40 \mathrm{~mm}$ (hollow-shaped cylinders). The samples are supported by tight-fitting aluminum rings which provide support for the metal sample holders (Fig. 5b, c). The combination of the metal holders and the soft aluminum rings insures a tight grip of the samples without applying excessive force on the samples themselves. Sample holders for gouges (non-cohesive rocks), a pressure vessel (for experiments to be performed in the presence of fluids) and a vacuum/environmental chamber equipped with mass spectrometer (for experiments to be performed in the absence of room humidity or in the presence of $\mathrm{N}_{2}, \mathrm{CO}, \mathrm{Ar}$ and $\mathrm{CO}_{2}$ ) are under development. 
Fig. 6 Preliminary experimental obtained with SHIVA. a Power and slip velocity output for experiment s007 (50/0 mm ext/int diameter). b, c Slip velocity, friction coefficient and shortening versus slip for solid (s011, 50/0 mm ext/int diameter) and hollow-shaped (s015, 50/32 mm ext/int diameter) cylinders of gabbro. See text for discussion

\subsubsection{Data acquisition}

We control and acquire data using a programmable automation controller, Compactrio (National Instruments), which allows data acquisition at rate up to $50 \mathrm{kHz}$ and real-time control of normal load, rotating speed and/or torque.

\subsection{Preliminary results}

We performed preliminary tests on solid (s007 and s011, $50 \mathrm{~mm}$ in diameter) and hollowshaped (s015, 32/50 $\mathrm{mm}$ int/ext diameter) cylinders of gabbro. The shear stress is determined from the torque $T$ measured by the S-beam load cell. In cylindrical specimens of radius $r$, each infinitesimal ring of surface $\mathrm{d} S=2 \pi r \mathrm{~d} r$ contributes to the total measured torque for $\mathrm{d} T=r \tau \mathrm{d} S=2 \pi \tau r^{2} \mathrm{~d} r$. Assuming that shear stress $\tau$ is constant over the fault surface $S$ (i.e., there is no or a small dependence of slip rate with shear stress, which is a reasonable approximation once some weakening mechanism has been activated in the slipping zone, Nielsen et al. 2008), the total measured torque is (Shimamoto and Tsutsumi 1994):

$$
T=\int_{r_{\text {int }}}^{r_{\text {ext }}} 2 \pi \tau r^{2} \mathrm{~d} r=\frac{2 \pi \tau}{3}\left(r_{\text {ext }}^{3}-r_{\text {int }}^{3}\right) \quad(\mathrm{Nm}),
$$

where $r_{\text {ext }}$ and $r_{\text {int }}$ are the external and internal radii of the specimen, respectively. Rearranging Eq. 5, we obtain:

$$
\tau=\frac{3 T}{2 \pi\left(r_{\mathrm{ext}}^{3}-r_{\mathrm{int}}^{3}\right)}
$$

which reduces to $\tau=3 T /\left(2 \pi r^{3}\right)$ in the particular case of solid cylinders $\left(r_{\text {int }}=0\right)$. Due to the cylindrical configuration of s007 and s011, slip rate increases from the centre to the periphery of the specimen, so here we introduce the equivalent slip rate $V_{\mathrm{e}}$ (Shimamoto and Tsutsumi 1994; Hirose and Shimamoto 2005). The power $P$ dissipated on the sliding surface is:

$$
P=S \tau V_{\mathrm{e}}=T \omega=2 T \pi R
$$

where $\omega=2 \pi R$ is the angular speed and $R$ is the rotation per minute or RPM. By replacing $\tau$ in Eq. 7:

$$
V_{\mathrm{e}}=\frac{4 \pi R\left(r_{\mathrm{ext}}^{2}+r_{\mathrm{ext}} r_{\mathrm{int}}+r_{\mathrm{int}}^{2}\right)}{3\left(r_{\mathrm{ext}}+r_{\mathrm{int}}\right)} \quad(\mathrm{m} / \mathrm{s}) .
$$

As a consequence, the displacement $d$ is:

$$
d=V_{\mathrm{e}} t \quad(\mathrm{~m})
$$

In Fig. 6a, we show the applied velocity and supplied power from the large engine (i.e., the power data are output data from the Gefran inverter/controller) for experiment s007 which was performed to test the maximum power output of the inverter/controller to the engine (see http://www.roma1.ingv.it/laboratori/laboratorio-hp-ht/usems-project and 

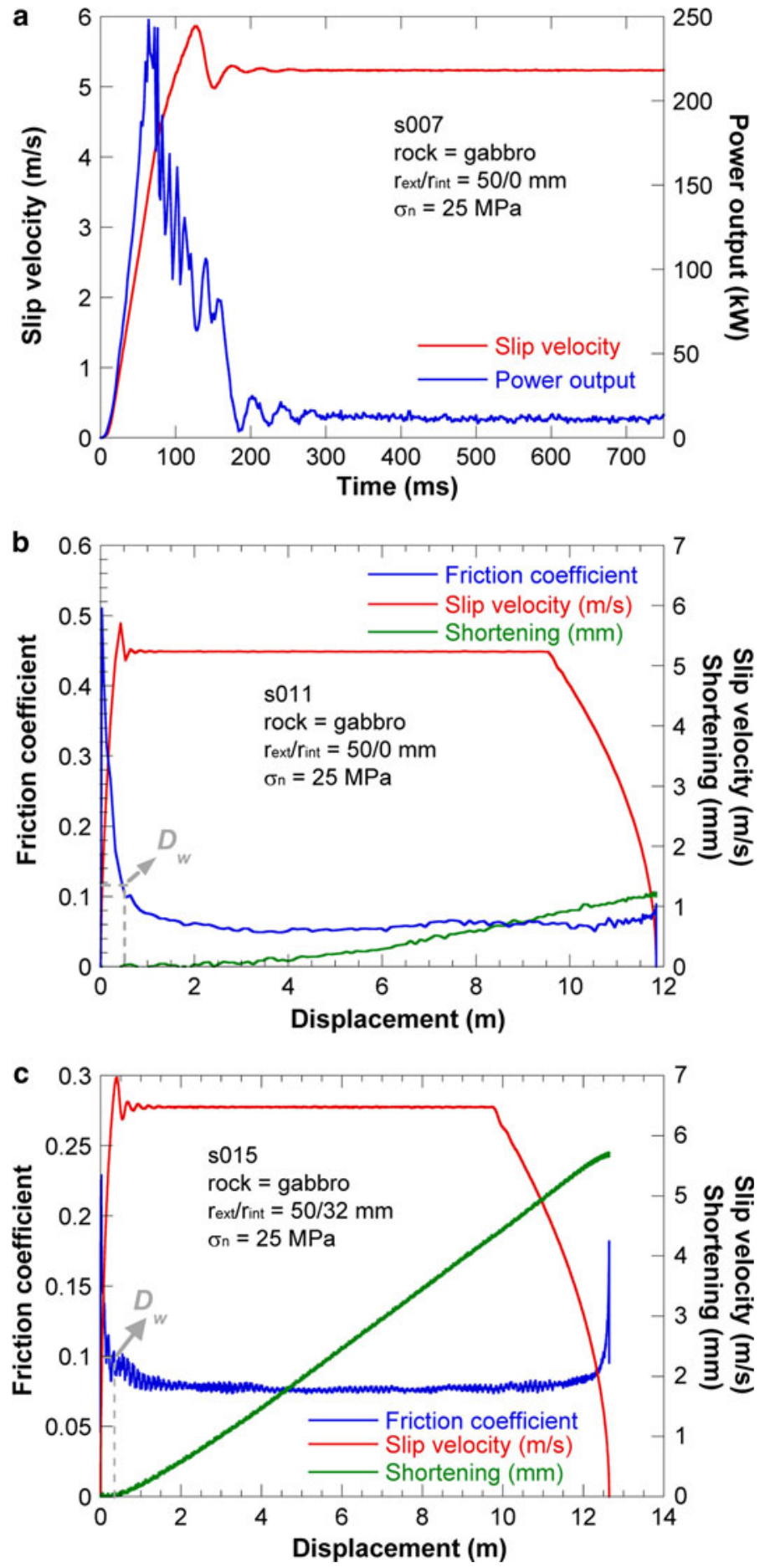
related links for a movie of the experiment). In order to achieve this, we applied the maximum normal load (50 kN corresponding to $\sim 25 \mathrm{MPa}$ on a solid cylinder) and the maximum acceleration (from 0 to $3,000 \mathrm{RPM}$ or $5.23 \mathrm{~m} \mathrm{~s}^{-1}$ for a $50 \mathrm{~mm}$ solid cylinder) allowed by the large engine. The velocity profile shows that the maximum engine speed and slip velocity were achieved within $110 \mathrm{~ms}$ (Fig. 6a). This corresponds to an acceleration on the sample of about $\sim 50 \mathrm{~m} \mathrm{~s}^{-2}$. There is an overshoot in velocity of about $10 \%$ which stabilizes to a constant velocity within $60 \mathrm{~ms}$ after the peak. The peak power supplied to the engine and thus the sample was $242 \mathrm{~kW}$, less than the maximum possible power. The peak in the power output occurred before the maximum speed was achieved, indicating that the sample was weakening during the abrupt acceleration at the initiation of sliding.

In Fig. 6b, we show the evolution of the friction coefficient (measured shear stress/ normal stress), sample shortening (measured by the LVDT), and slip velocity with displacement during experiment s011 performed under $25 \mathrm{MPa}$ normal stress on a pair of solid cylinders (50 $\mathrm{mm}$ in diameter) of gabbro. In Fig. 6c, we show the same parameters for experiment s015 performed with the same rock and normal stress but on hollow-shaped cylinders (32/50 $\mathrm{mm}$ int/ext diameter). In s011 and s015, we imposed the same acceleration of about $65 \mathrm{~m} \mathrm{~s}^{-2}$ and deceleration of $\sim 6 \mathrm{~m} \mathrm{~s}^{-2}$ ( $\sim 10$ times slower). The two experiments show:

1. a similar evolution of friction with slip. We observe an abrupt initial strengthening until a peak followed by a strong weakening towards a steady-state value. This experimental observation is in accordance with theoretical work (Nielsen et al. 2008) and is quite different from the experiments performed on similar rocks (gabbros) but under lower normal stresses $(<5 \mathrm{MPa})$ and slip rates $\left(<2 \mathrm{~m} \mathrm{~s}^{-1}\right)$ (e.g., Hirose and Shimamoto 2005; Tsutsumi and Shimamoto 1997). For lower stresses and slip rates (and accelerations), strong weakening is preceded by a complex evolution which includes first strengthening (similar to the abrupt strengthening we found), followed by first weakening (absent in our experiments), second strengthening (absent in our experiments) and final weakening towards steady state (similar but less abrupt than the one described here). The difference in the absolute value for the peak value in the friction coefficient $(0.5$ for $\mathrm{s} 011$ and 0.3 for $\mathrm{s} 015)$ is probably related to sample preparation: in the case of s015, the two opposite sliding surfaces were not perfectly parallel. An alternative interpretation is that friction melts covered the sliding surface of the hollow-shaped sample (during the accelerating stage) earlier than in the experiment with solid cylinders. In fact, the shortening rate of the hollow specimen (s015) is faster by several times than that of the solid specimen (s011) (Fig. 6b, c) and the stage of full melt lubrication started earlier run s015.

2. a steady-state friction coefficient around 0.07 which is similar to values previously measured in the presence of friction melt under large normal stress $(>15 \mathrm{MPa}$, Del Gaudio et al. 2009; Di Toro et al. 2006; Nielsen et al. 2008).

3 . an extremely rapid drop in shear stress. The slip weakening distance $D_{\mathrm{w}}$ (or the distance over which a significant decrease in shear stress occurs) is about $0.50 \mathrm{~m}$ in both cases. Movies of the experiments show that friction melting is near-instantaneous.

4. continuous shortening. For the solid cylinders (s011), shortening starts after about $2 \mathrm{~m}$ of slip and remains remarkably constant during the remainder of the experiment at a shortening rate of about $0.2 \mathrm{~mm} \mathrm{~m}^{-1}$ slip (or $1 \mathrm{~mm} \mathrm{~s}^{-1}$ ). In contrast, the hollowshaped sample starts shortening after a slip of only $\sim 1 \mathrm{~m}$ and shortens at a rate of about $0.5 \mathrm{~mm} \mathrm{~m}^{-1} \operatorname{slip}$ (or $2.5 \mathrm{~mm} \mathrm{~s}^{-1}$ ). 
5. a recovery of friction during the deceleration phase of the experiment. The amount of recovery of the shear stress (healing) is larger for hollow-shaped samples (about 0.1 for s015) than for the solid cylinders (about 0.02 for s011).

Experiments performed with SHIVA indicate that faults are lubricated after $0.1 \mathrm{~s}$ or few tens of centimeters under normal stresses $(25 \mathrm{MPa})$ that are still well below those expected at seismogenic depths. Although preliminary, these experiments suggest that melt lubrication might easily be achieved in nature (in the case of the crystalline rocks) and also confirm the large potential of SHIVA.

\section{Conclusions}

The large exposures of pseudotachylyte-bearing fault networks in the Southern Alps retain a wealth of information about earthquake source physics, information that is often hidden to seismological investigations. Further constraints are provided by experimental investigations using deformation apparatus capable of reproducing some characteristics of seismic slip. We recently installed at INGV in Rome a new state-of-the-art earthquake simulator called SHIVA. Preliminary experiments are extremely promising since the availability of high torque and power renders SHIVA extremely versatile. Experimental data collected with SHIVA under increasing normal loads, slip rates and accelerations will be critical for the determination of a constitutive law for rock friction at seismic slip rates. Experimental work will be carried out to investigate: (a) the mechanical properties of cohesive and non-cohesive (e.g., fault gouge) rocks during the seismic cycle, (b) the activation of seismic fault lubrication mechanisms, and (c) the role of fluids and temperature. Experiments with carbonates, evaporites and silicate-build rocks will produce, under controlled conditions, fault rock assemblages to be compared with natural fault rocks. During the experiments, it will be possible to measure the temperature achieved near the slipping zone (using infrared cameras and by inserting thermocouples in the specimens), the release of $\mathrm{CO}_{2}$ and $\mathrm{H}_{2} \mathrm{O}$ (e.g., decarbonation and dehydration reactions using a mass spectrometer-equipped vacuum chamber) and to investigate the effects of fluids in the frictional resistance (using a dedicated pressure vessel). These experiments will allow the study of tribochemical reactions of interest in Earth sciences, in contrast to those currently described in the ceramics and wear literature, which are mainly limited to pure silicon, silicon oxides, $\mathrm{Si}_{3} \mathrm{~N}_{4}$ and $\mathrm{SiC}$.

Lastly, the utilization of SHIVA has additional implications for understanding other friction-controlled processes important in Earth sciences and hazard mitigation (e.g., rock landslides). Friction also has broad applications in the industry, including innovative but poorly understood production processes. We aim to perform experiments that will help to improve industrial milling techniques and investigate the mechanical-chemical transformations induced during milling.

Acknowledgments We thank Francesco Paolo Sassi and Giorgio Vittorio Dal Piaz for encouraging us in writing this paper. G.D.T., A.N. and S.S wrote the manuscript. A.T., G.S., R.A., G.D.T., S.N. and P.S. worked on the design of SHIVA. F.D.F., A.N., S.N., G.R., G.D.S. and E.S. implemented the control and acquisition system of SHIVA. S.M. and P.S. managed the installation of SHIVA at INGV. We thank Toshihiko Shimamoto for discussions about an initial design of SHIVA. SHIVA was funded by the European Research Council Starting Grant 205175 USEMS (Principal Investigator G.D.T.) and by the Progetto FIRB "Development of innovative technologies for the environmental protection from natural events" (Principal Investigator P.S.). We acknowledge Enzo Boschi, Massimo Cocco and Antonio Piersanti for supporting the installation of SHIVA at INGV. 


\section{References}

Andrews DJ (2005) Rupture dynamics with energy loss outside the slip zone. J Geophys Res 110. doi: 101029/2004JB003191

Beeler NM (2006) Inferring earthquake source properties from laboratory observations and the scope of lab contributions to source physics. In: Abercrombie R, McGarr A, Di Toro G, Kanamori H (eds) Radiated energy and the physics of faulting. AGU Geophysical Monograph Series 170, Washington, DC, pp 99-119

Beeler NM, Tullis TE (1996) Self-healing slip pulse in dynamic rupture models due to velocity dependent strength. Bull Seismol Soc Am 86:1130-1148

Beeler NM, Tullis TE, Goldsby DL (2008) Constitutive relationships and physical basis of fault strength due to flash heating. J Geophys Res 113:B01401. doi:10.1029/2007JB004988

Bizzarri A, Cocco M (2006) A thermal pressurization model for the spontaneous dynamic rupture propagation on a three-dimensional fault. 1. Methodological approach. J Geophys Res 111:B05303. doi: 10.1029/2005JB003862

Brace WF, Byerlee JD (1966) Stick slip as a mechanism for earthquakes. Science 168:990-992

Brantut N, Schubnel A, Rouzaud JN, Brunet F, Shimamoto T (2008) High-velocity frictional properties of a clay bearing fault gouge and implications for earthquake mechanics. J Geophys Res 113:B10401. doi: 10.1029/2007JB005551

Brodsky EE, Kanamori H (2001) Elastohydrodynamic lubrication of faults. J Geophys Res 106:16,35716374

Byerlee JD (1978) Friction of rocks. Pure Appl Geophys 116:615-626

Chester JS, Chester FM, Kronenberg AK (2005) Fracture surface energy of the Punchbowl Fault, San Andreas System. Nature 437:133-136

Cocco M, Spudich P, Tinti E (2006) On the mechanical work absorbed on faults during earthquake ruptures. In: Abercrombie RE, McGarr A, Kanamori H, Di Toro G (eds) Radiated energy and the physics of earthquake faulting. AGU Monograph Series 170, Washington, DC, pp 237-254

Cowan DS (1999) Do faults preserve a record of seismic faulting? A field geologist's opinion. J Struct Geol 21:995-1001

Del Gaudio P, Di Toro G, Han R, Hirose T, Nielsen S, Shimamoto T, Cavallo A (2009) Frictional melting of peridotite and seismic slip. J Geophys Res 114. doi:1029/2008JB005990

Dieterich JH (1978) Time-dependent friction and the mechanics of stick-slip. Pure Appl Geophys 116:790-806

Dieterich JH (1979) Modeling of rock friction. 1. Experimental results and constitutive equations. J Geophys Res 84:2161-2168

Di Toro G, Pennacchioni G (2004) Superheated friction-induced melts in zoned pseudotachylytes within the Adamello tonalites (Italian Southern Alps). J Struct Geol 26:1783-1801

Di Toro G, Pennacchioni G (2005) Fault plane processes and mesoscopic structure of a strong-type seismogenic fault in tonalites (Adamello batholith, Southern Alps). Tectonophysics 402:54-79

Di Toro G, Goldsby DL, Tullis TE (2004) Friction falls towards zero in quartz rock as slip velocity approaches seismic rates. Nature 427:436-439

Di Toro G, Pennacchioni G, Teza G (2005a) Can pseudotachylytes be used to infer earthquake source parameters? An example of limitations in the study of exhumed faults. Tectonophysics 402:3-20

Di Toro G, Nielsen S, Pennacchioni G (2005b) Earthquake rupture dynamics frozen in exhumed ancient faults. Nature 436:1009-1012

Di Toro G, Hirose T, Nielsen S, Pennacchioni G, Shimamoto T (2006) Natural and experimental evidence of melt lubrication of faults during earthquakes. Science 311:647-649

Di Toro G, Nielsen S, Pennacchioni G (2009) Pseudotachylytes and earthquake source mechanics. In: Fukuyama E (ed) Fault-zone properties and earthquake rupture dynamics. International Geophysics Series. Elsevier, Amsterdam, pp 87-133

Fukuyama E, Mizoguchi K (2010) Constitutive parameters for earthquake rupture dynamics based on highvelocity friction tests with variable slip rate. Int J Fract 163:15-22

Goldsby DL, Tullis TE (2002) Low frictional strength of quartz rocks at subseismic slip rates. Geophys Res Lett 29. doi:10.1029/2002GL01240

Guatteri M, Spudich P (1998) Coseismic temporal changes of slip direction; the effect of absolute stress on dynamic rupture. Bull Seismol Soc Am 88:777-789

Guatteri M, Spudich P (2000) What can strong-motion data tell us about slip-weakening fault-friction laws? Bull Seismol Soc Am 90:98-116

Han R, Hirose T, Shimamoto T (2010) Strong velocity weakening and powder lubrication of simulated carbonate faults at seismic slip rates. J Geophys Res 115:B03412. doi:10.1029/2008JB006136 
Han R, Shimamoto T, Hirose T, Ree J-H, Ando J (2007) Ultralow friction of carbonate faults caused by thermal decomposition. Science 316:878-881

Hayashi N, Tsutsumi A (2010) Deformation textures and mechanical behavior of a hydrated amorphous silica formed along an experimentally produced fault in chert. Geophys Res Lett 37:L12305. doi: 10.1029/2010GL042943

Heaton TH (1990) Evidence for and implications of self healing pulses of slip in earthquake rupture. Phys Earth Planet Int 64:1-20

Hirose T, Shimamoto T (2005) Growth of molten zone as a mechanism of slip weakening of simulated faults in gabbro during frictional melting. J Geophys Res 110:B05202. doi:10.1029/2004JB003207

Jeffreys H (1942) On the mechanics of faulting. Geol Mag 79:291-295

Kame N, Rice JR, Dmowska R (2003) Effects of pre-stress state and rupture velocity on dynamic fault branching. J Geophys Res 108:B2205. doi:10.1029/2002JB002189

Kanamori H, Brodsky E (2004) The physics of earthquakes. Rep Prog Phys 67:1429-1496

Kitajima H, Chester JS, Chester FM, Shimamoto T (2010) High-speed friction of disaggregated ultracataclasite in rotary shear: characterization of frictional heating, mechanical behavior, and microstructure evolution. J Geophys Res. doi:10.1029/2009JB007038

Kostrov B, Das S (1988) Principles of earthquake source mechanics. Cambridge University Press, London

Lachenbruch AH (1980) Frictional heating, fluid pressure, and the resistance to fault motion. J Geophys Res 85:6249-6272

Lee WH, Kanamori H, Jennings PC, Kisslinger C (2002) Earthquake \& engineering seismology, vol 1 and 2. Academic Press, Amsterdam

Lockner DA, Beeler NM (2002) Rock failure and earthquakes. In: Lee WH, Kanamori H, Jennings PC, Kisslinger C (eds) Earthquake \& engineering seismology. Academic Press, Amsterdam, pp 505-537

Marone C (1998) Laboratory-derived friction laws and their application to seismic faulting. Annu Rev Earth Planet Sci 26:643-696

Mayeda K, Walter WR (1996) Moment, energy, stress drop, and source spectra of western United States earthquakes from regional coda envelopes. J Geophys Res 101:11195-11208

McKenzie D, Brune JN (1972) Melting on fault planes during large earthquakes. Geophys J R Astron Soc 29:65-78

Melosh J (1996) Dynamic weakening of faults by acoustic fluidization. Nature 397:601-606

Nielsen S, Di Toro G, Hirose T, Shimamoto T (2008) Frictional melt and seismic slip. J Geophys Res 113:B01308. doi:10.1029/2007JB0051222008

Pennacchioni G, Di Toro G, Brack P, Menegon L, Villa IM (2006) Brittle-ductile-brittle deformation during cooling of tonalite (Adamello, Southern Italian Alps). Tectonophysics 427:171-197

Pittarello L, Di Toro G, Bizzarri A, Pennacchioni G, Hadizadeh J, Cocco M (2008) Energy partitioning during seismic slip in pseudotachylyte-bearing faults (Gole Larghe Fault, Adamello, Italy). Earth Planet Sci Lett 269:131-139

Poliakov ANB, Dmowska R, Rice JR (2002) Dynamic shear rupture interactions with fault bends and offaxis secondary faulting. J Geophys Res 107:B2295. doi:10.1029/2001JB000572

Reches Z, Lockner DA, Chang JC, Totten MW (2009) Earthquake-like slip events on an analog laboratory fault. 2009 Southern California Earthquake Center Annual Meeting Proceedings and Abstracts, vol 19, p 320

Rice JR (2006) Heating and weakening of faults during earthquake slip. J Geophys Res 111:B05311. doi: 10.1029/2005JB004006

Ruina A (1983) Slip instability and state variable friction laws. J Geophys Res 88:10359-10370

Schmid SM, Aebli HR, Heller F, Zingg A (1989) The role of the Periadratic Line in the tectonic evolution of the Alps. In: Coward MP, Dietrich D, Park RG (eds) Alpine tectonics. Geological Society Special Publication 45, London, pp 153-171

Scholz CH (1998) Earthquakes and friction laws. Nature 391:37-42

Scholz CH (2002) The mechanics of earthquakes and faulting. Cambridge University Press, Cambridge

Shand SJ (1916) The pseudotachylyte of Parijs (Orange Free State) and its relation to "trap-shotten gneiss" and "flinty crush rock". Q J Geol Soc Lond 72:198-221

Shimamoto T, Tsutsumi A (1994) A new rotary-shear high-speed frictional testing machine: its basic design and scope of research. J Tecton Res Group Jpn 39:65-78 (in Japanese with English abstract)

Sibson RH (1973) Interactions between temperature and pore fluid pressure during earthquake faulting-a mechanism for partial or total stress relief. Nature 243:66-68

Sibson RH (1975) Generation of pseudotachylyte by ancient seismic faulting. Geophys J R Astron Soc 43:775-794 
Sibson RH, Toy V (2006) The habitat of fault-generated pseudotachylyte: presence vs. absence of friction melt. In: Abercrombie R, McGarr A, Di Toro G, Kanamori H (eds) Radiated energy and the physics of faulting. AGU Geophysical Monograph Series 170, Washington, DC, pp 153-166

Sone H, Shimamoto T (2009) Frictional resistance of faults during accelerating and decelerating earthquake slip. Nat Geosci 2:705-708

Spray JG (1987) Artificial generation of pseudotachylyte using friction welding apparatus: simulation of melting on a fault plane. J Struct Geol 9:49-60

Spray JG (1992) A physical basis for the frictional melting of some rock forming minerals. Tectonophysics 204:205-221

Spray JG (1995) Pseudotachylyte controversy: fact or friction? Geology 23:1119-1122

Spray JG (2005) Evidence for melt lubrication during large earthquakes. Geophys Res Lett 32:L07301. doi: 10.1029/2004GL022293

Swanson MT (1992) Fault structure, wear mechanisms and rupture processes in pseudotachylyte generation. Tectonophysics 204:223-242

Tisato N, Di Toro G, De Rossi N, Quaresimin M (2009) Experimental investigation of flash weakening in limestones. South California Earthquake Center Annual Meeting, Palm Springs, USA

Tripoli A (2008) High velocity rock friction apparatus, Progetto Preliminare. Project Report TA-2007-3-Rev 1 (in Italian)

Tsutsumi A, Shimamoto T (1997) High velocity frictional properties of gabbro. Geophys Res Lett 24:699-702

Tullis TE (1988) Rock friction constitutive behavior from laboratory experiments and its implications for an earthquake prediction field monitoring program. Pure Appl Geophys 126:556-588

Tullis TE (2008) Rheology of fault rocks and their surrounding. In: Handy MR, Hirth G, Hovious N (eds) Tectonic faults. The MIT press, Cambridge, pp 183-204

Venturelli G, Thorpe RS, Dal Piaz GV, Potts PJ (1984) Petrogenesis of calc-alkaline, shoshonitic and associated ultrapotassic Oligocene volcanic rocks from the northwestern Alps, Italy. Contr Miner Petrol 86:209-220

Wibberley CAJ, Graham Y, Di Toro G (2008) Recent advances in the understanding of fault zone internal structure: a review. In: Wibberley CAJ, Kurz W, Imber J, Holdsworth RE, Collettini C (eds) The internal structure of fault zones-implications for mechanical and fluid flow properties. Special Volume of the Geological Society of London 299, pp 5-33

Yuan F, Prakash V (2008a) Use a modified torsional Kolsky bar to study frictional resistance in rock-analog materials. Int J Solids Struct 45:4247-4263

Yuan F, Prakash V (2008b) Slip weakening in rocks and analog materials at co-seismic slip rates. J Mech Phys Sol 56:542-560

Zheng G, Rice JR (1998) Conditions under which velocity-weakening friction allows a self-healing versus a crack-like Mode of rupture. Bull Seismol Soc Am 88:1466-1483 